\title{
15. OLEANENE, URSENE, AND OTHER TERRIGENOUS TRITERPENOID BIOLOGICAL-MARKER HYDROCARBONS IN BAFFIN BAY SEDIMENTS 1
}

\author{
H. Lo ten Haven ${ }^{2}$ and Jürgen Rullkötter ${ }^{2}$
}

\begin{abstract}
The aliphatic hydrocarbon fractions of eight early Miocene to Pliocene sediment samples from Hole 645E (Baffin Bay; ODP Leg 105) were investigated by gas chromatography and gas chromatography/mass spectrometry. Long, straight-chain alkanes of terrigenous origin are often present as major compounds. Other terrigenous biological markers include three oleanenes with a double bond at positions 12,13(18), or 18, and taraxer-14-ene. Urs-12-ene is identified tentatively. In the three deepest samples, $17 \alpha(\mathrm{H}), 18 \alpha(\mathrm{H})$, and $21 \beta(\mathrm{H})-28,30$-bisnorhopane is the most abundant compound. Several new compounds were detected, some of which are tentatively identified. The identification and possible significance of 23-norlupane, three A/B-ring nuclear demethylated (or A-nor-) oleanenes, and an A/B-ring nuclear demethylated (or A-nor-) urs-12-ene are discussed. The authors postulate that taraxer-14-ene isomerizes to olean12-ene with increasing burial depth.
\end{abstract}

\section{INTRODUCTION}

The continental shelf areas of Baffin Bay and Davis Strait were important areas for oil exploration in the mid-1970s. However, drilling was unsuccessful, although some source rocks having a potential mainly for gas were encountered (Rolle, 1985). Site 645 is located on the continental slope off southern Baffin Island in a water depth of $2020 \mathrm{~m}$ (Fig. 1). The sediments recovered while drilling seven holes are considered to represent almost a continuous record well into the early Miocene. This sediment sequence shows a pronounced terrigenous fraction almost devoid of fossils (Shipboard Scientific Party, 1987). Organic matter is predominantly of kerogen type III (Stein et al., this volume), which corroborates with the gas potential of source rocks as reported by Rolle (1985) for the Davis Strait area. Our objective was to examine the distributions of biological-marker hydrocarbons for evidence of this apparently strong terrigenous influence. In addition, we searched for diagenetic organic-geochemical changes occurring with depth.

\section{METHODS AND PROCEDURES}

Eight samples from Hole 645E were investigated (Table 1). All are from lithologic Unit III (Shipboard Scientific Party, 1987) and were selected on the basis of organic-petrographic differences as reported by Stein et al. (this volume). Standard laboratory procedures are described elsewhere (e.g., Rullkötter et al., 1987). Gas chromatography of the aliphatic hydrocarbon fractions was performed using a Hewlett-Packard 5710A gas chromatograph equipped with a Gerstel programmed temperature-injector system (KAS, Gerstel, Mülheim/Ruhr) and a fused silica capillary column (length $=25 \mathrm{~m}$; inside diameter $=0.32 \mathrm{~mm}$ ) coated with CP Sil 8 . Helium was used as carrier gas, and the temperature was programmed from $80^{\circ}$ to $300^{\circ} \mathrm{C}$ at $4^{\circ} \mathrm{C} / \mathrm{min}$. Gas chromatography/mass spectrometry was conducted using a Carlo Erba Fractovap 4160 gas chromatograph coupled to a VG $7070 \mathrm{E}$ mass spectrometer operating at $70 \mathrm{eV}$. Samples were injected, using the on-column mode, onto a fused silica capillary column (length $=25 \mathrm{~m}$; inside diameter = $0.32 \mathrm{~mm}$ ) coated with SE 54. Helium was used as carrier gas, and the temperature was programmed from $110^{\circ}$ to $320^{\circ} \mathrm{C}$ at $3^{\circ} \mathrm{C} / \mathrm{min}$.

\footnotetext{
${ }^{1}$ Srivastava, S. P., Arthur, M. A., Clement, B., et al., 1989. Proc. ODP, Sci. Results, 105: College Station, TX (Ocean Drilling Program).

2 Institut für Erdöl und Organische Geochemie (ICH-5), KFA Jülich, Postfach 1913, D-5170 Jülich, Federal Republic of Germany.
}

\section{RESULTS}

An example of a gas chromatogram of an aliphatic hydrocarbon fraction is shown in Figure 2. The distribution of the normal alkanes is dominated by long-chain homologues in all samples, especially $n-\mathrm{C}_{25} \mathrm{H}_{52}, n-\mathrm{C}_{27} \mathrm{H}_{56}, n-\mathrm{C}_{29} \mathrm{H}_{60}$, and $n-\mathrm{C}_{31} \mathrm{H}_{64}$. Pristane/phytane concentration ratios vary between 0.9 and 1.1 and show no correlation with depth. Major differences between the samples were observed with respect to several compounds eluting between $n-\mathrm{C}_{27} \mathrm{H}_{52}$ and $n-\mathrm{C}_{35} \mathrm{H}_{72}$. Thus, attention was focussed on that particular elution range.

Partial gas chromatograms of the $n-\mathrm{C}_{27} \mathrm{H}_{56}$ to $n-\mathrm{C}_{35} \mathrm{H}_{72}$ range of the eight samples are shown in Figure 3. The straight-chain alkanes are indicated by black in these figures. Peak numbers correspond to those listed in Table 2. Identifications are based on comparison of mass spectra and relative retention times with those described in the literature. Tentative assignments were made where no literature data were available. The structures of selected compounds are presented in the Appendix; these structures are referred to in the text with Roman numerals.

The major cyclic hydrocarbons in the geologically youngest samples (Figs. 3A and 3B) are taraxer-14-ene (13, I) and olean12-ene $(15, \mathrm{II})$. The former compound coelutes with the $n-\mathrm{C}_{30} \mathrm{H}_{62}$ alkane on the capillary column used. In addition, two other oleanenes, olean-13(18)-ene (14a, III) and olean-18-ene (16, IV), are identified. This elution sequence of oleanenes agrees with the elution data reported by Hoffmann et al. (1984), which were obtained for a capillary column coated with CP Sil 5. Peak 18 represents two compounds that were identified as 30-normoretane and urs-12-ene (V) (Fig. 3). Urs-12-ene and olean-12-ene have almost identical spectra but can be differentiated on the basis of the m/z 191/203 ratio (see Karliner and Djerassi, 1966). Because of coelution of 30-normoretane, this criterion was not applied here. However, oleanane series compounds always elute before the equivalent ursane triterpenoids on silicone columns (e.g., Fokina, 1979; Burnouf-Radosevich et al., 1985). Other compounds indicated in Figure 3 are saturated and monounsaturated members of the hopane family, of which $17 \beta(\mathrm{H}), 21 \beta(\mathrm{H})-$ homohopane $(24, \mathrm{IX})$ is the most abundant compound.

Those samples from a depth of $760.0 \mathrm{~m}$ and $766.5 \mathrm{~m}$ are similar to each other (Figs. 3C and 3D), but clearly different from the samples discussed above. The mass spectra of the major compounds, 9 and 12, are shown in Figure 4, together with the mass spectrum of olean-12-ene (15). Compounds 9 and 12 have similar mass spectra and their similarity to the spectrum of 


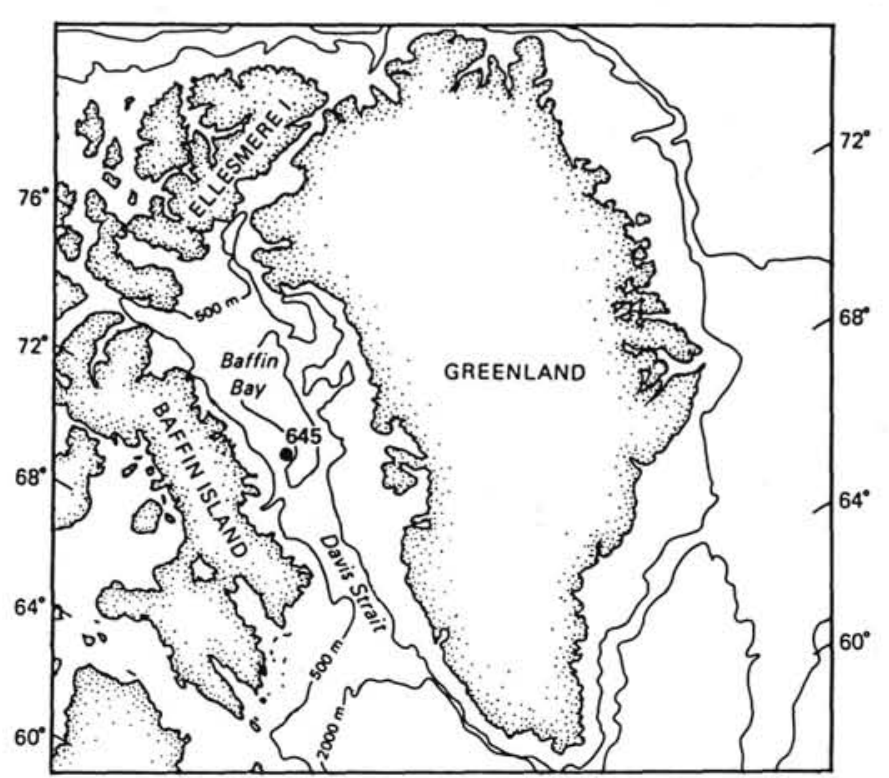

Figure 1. Location map of Baffin Bay showing Site 645.

Table 1. Depth, age, organic-carbon, and lithology data for sediment samples from Hole 645E.

\begin{tabular}{lrlrll}
\hline $\begin{array}{c}\text { Sample } \\
\text { interval (cm) }\end{array}$ & $\begin{array}{c}\text { Depth } \\
\text { (mbsf) }\end{array}$ & \multicolumn{1}{c}{$\begin{array}{c}\text { Age } \\
(\mathrm{m} . \mathrm{y})\end{array}$} & $\begin{array}{c}\mathrm{C}_{\text {org }} \\
(\%)\end{array}$ & $\begin{array}{c}\text { Lithological } \\
\text { Unit* }\end{array}$ \\
\hline 105-645E-8-5, 21 & 499.9 & e. Plio.(?) & 4.9 & 1.12 & IIIA \\
$105-645 \mathrm{E}-22-2,86$ & 626.9 & m. Mio.(?) & 9.2 & 0.96 & IIIA \\
$105-645 \mathrm{E}-37-5,63$ & 760.0 & m. Mio. & 12.0 & 1.08 & IIIB \\
$105-645 \mathrm{E}-36-3,47$ & 766.5 & m. Mio. & 12.1 & 0.99 & IIIB \\
$105-645 \mathrm{E}-39-4,134$ & 776.1 & m. Mio. & 12.3 & 1.11 & IIIB \\
$105-645 \mathrm{E}-57-4,99$ & 941.7 & m. Mio. & 15.7 & 0.63 & IIIC \\
$105-645 \mathrm{E}-64-5,94$ & 1010.6 & e. Mio. & 17.2 & 1.47 & IIIC \\
$105-645 \mathrm{E}-71-4,133$ & 1076.9 & e. Mio. & 16.2 & 0.61 & IIIC \\
\hline
\end{tabular}

- See site chapter (Shipboard Scientific Party, 1987).

olean-12-ene points to an oleanene/ursene skeleton. However, their molecular ions are shifted to $\mathrm{m} / \mathrm{z} 396$. The base peak of olean-12-ene and urs-12-ene is derived from the D/E-rings by cleavage through ring $\mathrm{C}$, which involves a retro-Diels-Alder reaction. The fragment at $\mathrm{m} / \mathrm{z} 191$ is derived from the A/B-rings (see Karliner and Djerassi [1966] for more specific information about fragments at $\mathrm{m} / \mathrm{z} 189,203$, and 257). Compounds 9 and 12 lack the typical m/z 191 fragment, which indicates that a methylene unit $\left(\mathrm{CH}_{2}\right)$ is missing from the A/B ring part of the molecule. The mass spectrum of compound 9 shows a more intense $\mathrm{m} / \mathrm{z} 203$ fragment (35\%) than the mass spectrum of compound $12(16 \%)$, a phenomenon also observed in the mass spectra of olean-12-ene and urs-12-ene, respectively (Karliner and Djerassi, 1966). Thus, we tentatively identified compounds 9 and 12 as A/B-ring nuclear demethylated olean-12-ene and urs12-ene, respectively, or as the corresponding A-nor species. Compounds 8 and 10 have mass spectra similar to those of olean13(18)-ene and olean-18-ene, respectively, but their molecular ions are shifted 14 daltons to $\mathrm{m} / \mathrm{z} 396$. By analogy with the above discussion of compounds 9 and 12 , we tentatively identified compound 8 as an A/B-ring nuclear demethylated olean13(18)-ene and compound 10 as an A/B-ring nuclear demethylated olean-18-ene (or as the corresponding A-nor compounds). The elution sequence of these tentatively identified nor-oleanenes $(8,9,10)$ is thus similar to that of the regular oleanenes $(14 \mathrm{a}$, $15,16)$. Brassell $(1980)$ also tentatively identified a $\Delta^{12} C_{29}$ triterpane in sediments from the Japan Trench. The mass spectro-

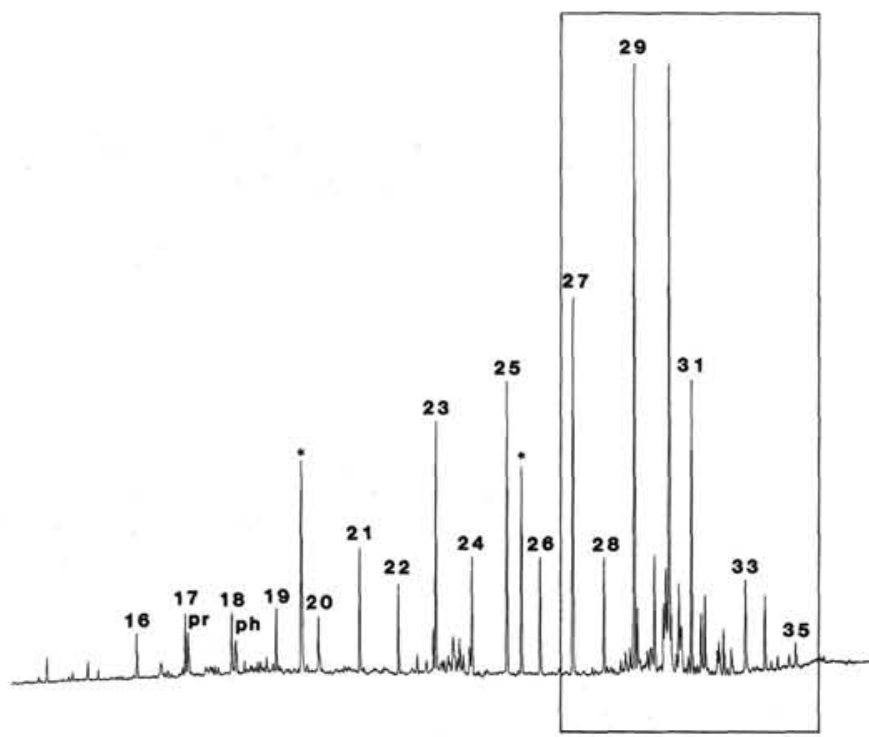

Figure 2. Gas chromatogram of the aliphatic hydrocarbon fraction (middle Miocene, $778.1 \mathrm{~m}$ ) of Sample 105-645E-29-4, $134 \mathrm{~cm}$. Straight chain alkanes are labeled with numbers corresponding to their number of carbon atoms. Contaminants are indicated with an asterisk. $P r$ and $P h$ indicate the isoprenoid hydrocarbons, pristane and phytane, respectively. The $n-\mathrm{C}_{27} \mathrm{H}_{56} / n-\mathrm{C}_{35} \mathrm{H}_{72}$ range corresponds to Figure $3 \mathrm{E}$.

metric characteristics $\left[\mathrm{M}^{+}\right.$396(10), 381(5), 218(100), 203(30)] suggest that this may be identical to our component 9 . Brassell postulated that the compound has a photochemically or bacterially degraded A-ring, i.e., the former six-membered ring was transformed into a five-membered ring (A-nor triterpane; see Corbet et al., 1980).

The mass spectrum of the third most abundant compound (14b) is shown in Figure 5. The molecular ion at $\mathrm{m} / \mathrm{z} 398$ points to an elemental composition of $\mathrm{C}_{29} \mathrm{H}_{50}$, and the (M-43) ${ }^{+}$fragment indicates the presence of an intact isopropyl side-chain. The fragment at $\mathrm{m} / \mathrm{z} 206$ seems characteristic of the lupane series (Budzikiewicz et al., 1963), and the base peak at $\mathrm{m} / \mathrm{z} 177$ points to the loss of a methylene unit from the A- or B-ring. By comparison with mass spectra of 23,28 -bisnor-, and 28-norlupanes (Rullkötter et al., 1982), we identified compound $14 \mathrm{~b}$ as a 23-norlupane.

Three more compounds with unknown structures $(3 a, 7,11 a)$ occur in the Hole $645 \mathrm{E}$ samples. Compound 11a is characterized by a molecular ion at $\mathrm{m} / \mathrm{z} 382(10 \%)$, a base peak at $\mathrm{m} / \mathrm{z}$ 163 , and a rearrangement ion at $\mathrm{m} / \mathrm{z} 190(30 \%)$. The mass spectrum of compound $3 \mathrm{a}$ is shown in Figure 6. Compound 7 exhibits a similar spectrum. The mass spectra of these compounds indicate that the structures are remarkably stable under electron impact, as the molecular ions are intense peaks (base peak in 7). We can only speculate about their structures, but note that their mass spectra show similarities with a dehydration product of $\beta$ amyrin, with double bonds at positions 12 and 14 and a molecular ion (base peak) at $\mathrm{m} / \mathrm{z} 408$ (Elgamal et al., 1969). The molecular ions of compounds $3 \mathrm{a}$ and 7 are 14 daltons less, but the relatively important fragment at $\mathrm{m} / \mathrm{z} 255$, which results from cleavage across ring B (Elgamal et al., 1969), does not shift to lower values. This implies loss of a methylene unit from ring A, analogous to what we interpretated for compounds $8,9,10$, and 12.

The sample from a depth of $778.1 \mathrm{~m}$ (Fig. 3E) is similar to the samples from depths of $499.9 \mathrm{~m}$ and $626.9 \mathrm{~m}$ (Figs. 3A and $3 \mathrm{~B})$, but it lacks taraxer-14-ene (13) and contains the unknown compound $11 \mathrm{a}$. In addition, a compound having similar characteristics as compound 11a but with a molecular ion at $\mathrm{m} / \mathrm{z} 326$ 
was detected in the $n-\mathrm{C}_{23} \mathrm{H}_{48} / n-\mathrm{C}_{24} \mathrm{H}_{50}$ range (Fig. 2). In this same elution range, two compounds were identified as des- $\mathrm{A}$ urs-12-ene (VI) and des-A-lup-5(10)-ene (VII), the mass spectra of which were reported by Corbet (1980).

The geologically oldest samples (Figs. $3 \mathrm{~F}$ to $3 \mathrm{H}$ ) are characterized by a number of compounds not observed in the other samples. The major compound (11b) is identified as $17 \alpha(\mathrm{H})$, $18 \alpha(\mathrm{H}), 21 \beta(\mathrm{H})-28,30$-bisnorhopane. The fragment at $\mathrm{m} / \mathrm{z} 163$ is somewhat enhanced (49\%), compared to literature data (Seifert et al., 1978). However, careful scanning of the front and rear sides of this peak revealed the presence of the unknown compound $11 \mathrm{a}$, with its base peak at $\mathrm{m} / \mathrm{z} 163$. Compounds 1,2 , and $3 \mathrm{~b}$ are unknowns, and the mass spectra are shown in Figure 6. Compound $3 \mathrm{~b}$ is most probably a homologue of compound 2 , because the major fragments have shifted 14 daltons $(\mathrm{m} / \mathrm{z}$ 229 to $\mathrm{m} / \mathrm{z} 243 ; \mathrm{m} / \mathrm{z} 367$ to $\mathrm{m} / \mathrm{z} 381 ; \mathrm{m} / \mathrm{z} 382$ to $\mathrm{m} / \mathrm{z} 396$ ). In the mass spectrum of compound $3 \mathrm{~b}$, some fragments can be ascribed to coelution of compound $3 \mathrm{a}$.

Diasterenes were identified in small amounts only in the three oldest samples (not indicated in Fig. 3). The 24-ethyl diacholest-13(17)-enes $\left(\mathrm{C}_{29}\right)$ are more abundant than the $\mathrm{C}_{27}$ and $\mathrm{C}_{28}$ homologues. The $20 \mathrm{R}$ isomers (e.g., $\mathrm{X}$ ) are present in higher concentrations than the $20 \mathrm{~S}$ isomers (e.g., $\mathrm{XI}$ ), although there is poor resolution between the $20 \mathrm{R}-\mathrm{C}_{28}$ diasterene and the $20 \mathrm{~S}-\mathrm{C}_{29}$ diasterene (see Brassell et al., 1984).

\section{DISCUSSION}

\section{Biological Markers}

The $n$-alkanes in the higher molecular weight range all have a similar distribution pattern (Figs. $3 \mathrm{~A}$ to $3 \mathrm{H}$ ) and show a strong odd-over-even carbon number predominance. Nonacosane $(n-$ $\mathrm{C}_{29} \mathrm{H}_{60}$ ) is the most abundant alkane. The distribution of the earlier eluting alkanes varies little. This kind of distribution pattern indicates an origin from higher plants (Eglinton and Hamilton, 1963). Carbon-preference-index (CPI) values were not calculated because of coelution of compound 5 with $n-\mathrm{C}_{29} \mathrm{H}_{60}$ and compound 13 with $n-\mathrm{C}_{30} \mathrm{H}_{62}$ in some samples. Nevertheless, Figures 2 and 3 indicate that CPI values are very high for Baffin Bay sediments.

As stated previously, the selection of samples for this study of biological markers was based on data derived from kerogen microscopy (Stein et al., this volume). A high alginite content $(30 \%-50 \%)$, together with an increased Hydrogen Index (from Rock-Eval pyrolysis) of the organic matter that was interpreted as the result of an enhanced marine influx, was observed in samples from depths of $626.9 \mathrm{~m}, 760.0 \mathrm{~m}$, and $766.5 \mathrm{~m}$, respectively, while the alginite content of the other samples was low $(0 \%-10 \%)$. These petrographic differences are clearly not corroborated here.

A possible explanation for this discrepancy is that at the stage of diagenesis encountered in the Hole 645E sediments, marine biological markers still occur as functionalized components (e.g., sterols), whereas part of the terrigenous precursors are defunctionalized at an earlier stage and thus can already be identified in the aliphatic hydrocarbon fraction. McEvoy and Maxwell (1983), among others, showed that sterols in deep-sea sediments can survive at greater depths even in areas of high heat flow (offshore California). Future investigations of the alcohol, ketone, and fatty acid fractions of the Hole 645E sediments will evaluate our hypothesis.

The composition of the aliphatic biological-marker hydrocarbons is unusual in many aspects. An origin from terrigenous higher plants for most compounds (if not all) seems irrefutable. A variety of pentacyclic triterpenoids with oleanane, ursane, taraxerane, lupane, and friedelane skeletons have been identified in higher plants, but not in marine organisms. In sediments, the most frequently encountered members of these terrigenous biological markers are those having $\beta$-amyrin (oleanane) and $\alpha$-amyrin (ursane) skeletons (Brassell and Eglinton, 1986). However, a dominance of these compounds, as observed in sediments from Baffin Bay, has not yet been reported for deep-sea sediments. Oleananes have been detected in some deltaic sequences, such as the Niger Delta (Ekweozor et al., 1979a) and the Mahakam Delta (Hoffmann et al., 1984). These deltaic environments are also characterized by the occurrence of ring-A-degraded triterpanes (see Baas, 1985, for an overview); these compounds (e.g., VI, VII) are present in relatively low amounts in Baffin Bay sediments. Ring-A-degraded triterpenes are thought to be products of microbial breakdown of seco-A-triterpenes, which, in turn, may originate from unchanged seco-A-triterpenoids (Baas, 1985), or may be the result of photochemical or photomimetic degradation of triterpenoids (Corbet et al., 1980; Schmitter et al., 1981). However, Baas (1985) suggested that at least part of the degradation of the A-ring may also occur in the plant prior to sedimentation. Apparently, many mechanisms seem to play an active role in the A-ring degradation of triterpenoids, but a functional group at $\mathrm{C}-3$ seems to be a prerequisite. To our knowledge, precursors for the tentatively identified nuclear demethylated compounds $(8,9,10,12)$ have not been reported in the geochemical literature, but the corresponding geochemical reactions are known for diterpenoids (e.g., degradation of abietic acid; Simoneit, 1975). We believe that the triterpenoid precursors are functionalized at C-23 (or C-24), but not at C-3. A similar reason can be given for the precursor of the tentatively identified 23-norlupane.

In Tertiary sediments from adjacent land sections in West Greenland, Rullkötter et al. (1982) identified a pair of isomeric nuclear demethylated triterpanes having a lupane skeleton. The absence of any specific precursor led them to suggest that a specific reaction sequence with probable microbial intervention under restricted environmental conditions might be responsible for the formation of the 23,28-bisnorlupanes. These compounds were also detected in sediments from the Beaufort-Mackenzie Delta (Brooks, 1986) and the Gulf of Suez (Rullkötter et al., 1982). Restricted environmental conditions cannot be invoked for sediments investigated here and, therefore, may not be responsible for the formation of the nuclear demethylated triterpanes in Baffin Bay. Investigations of the heterocompound fractions may provide the crucial information necessary for conclusions about precursors and their diagenetic pathways.

\section{Diagenetic Transformations}

Lipid transformation processes in sediments have been the subject of many studies. In particular, the diagenetic fate of steroids was studied in detail (Mackenzie et al., 1982; Brassell et al., 1984). Steroidal hydrocarbons were virtually absent in Baffin Bay sediments, but some traces of $20 \mathrm{R}$ and $20 \mathrm{~S}$ diasterenes were detected in the three deepest samples, using mass fragmentography of $\mathrm{m} / \mathrm{z} 257$. An increase in the relative concentration of the $20 \mathrm{~S}$ isomer was observed with increasing burial depth, similar to results obtained by Brassell et al. (1984) for deep-sea sediments from other locations. The diasterene isomerization ends with a 1:1 mixture of $20 \mathrm{~S}$ and $20 \mathrm{R}$ isomers, but this end point was not reached at a depth of $1076.9 \mathrm{~m}$ in Hole 645E. Concomitant with the occurrence of diasterenes is the first appearance of $17 \alpha(\mathrm{H}), 18 \alpha(\mathrm{H}), 21 \beta(\mathrm{H})-28,30$-bisnorhopane (Fig. 3F; compound $11 \mathrm{~b}$ ). Note that the relative concentration of this bisnorhopane increases with burial depth (Figs. $3 \mathrm{~F}$ to $3 \mathrm{H}$ ), a behavior similar to that of the $20 \mathrm{~S}$ diasterenes.

The relative concentration of taraxer-14-ene decreases with depth, while in the same interval the relative concentration of 

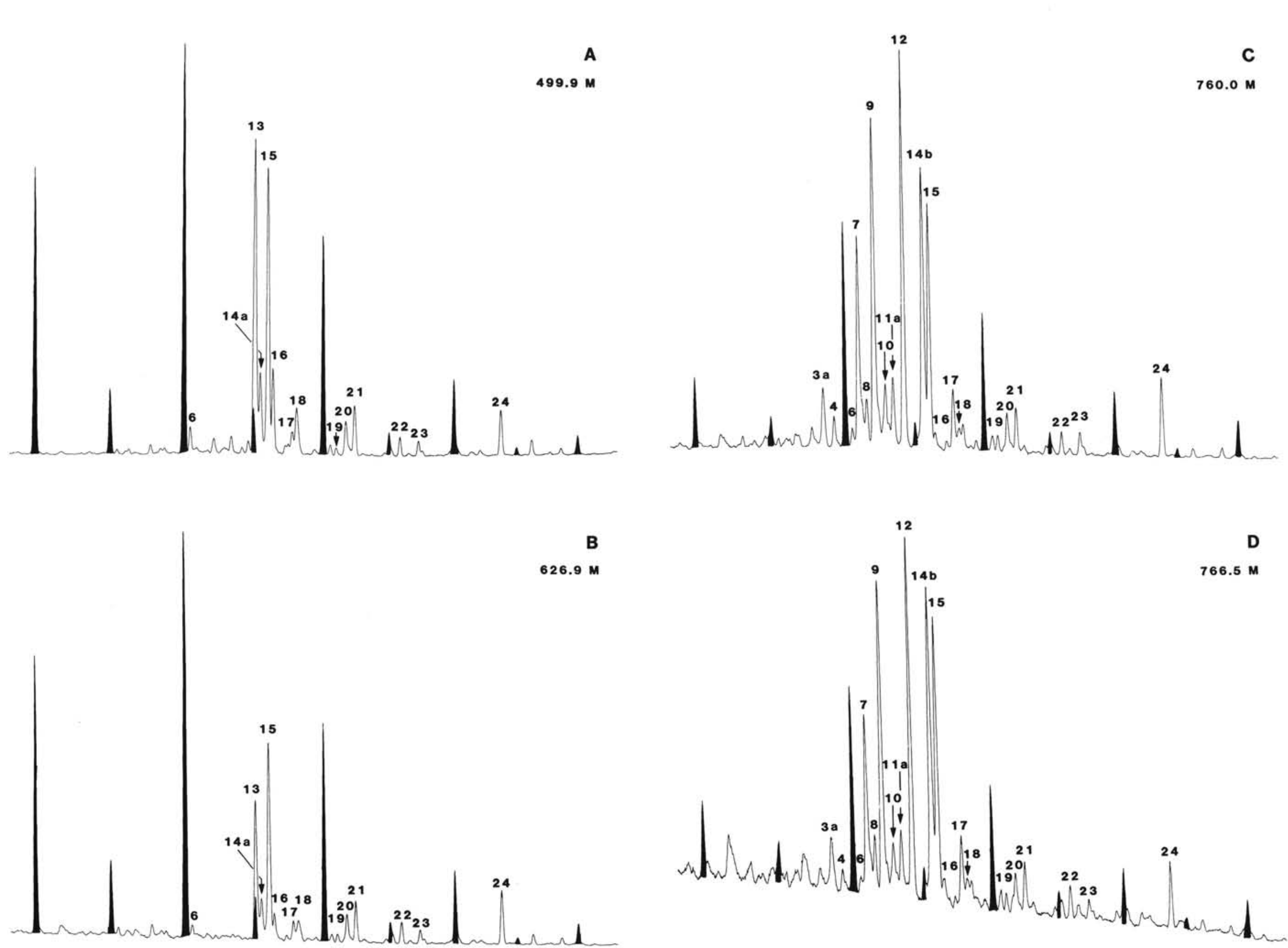

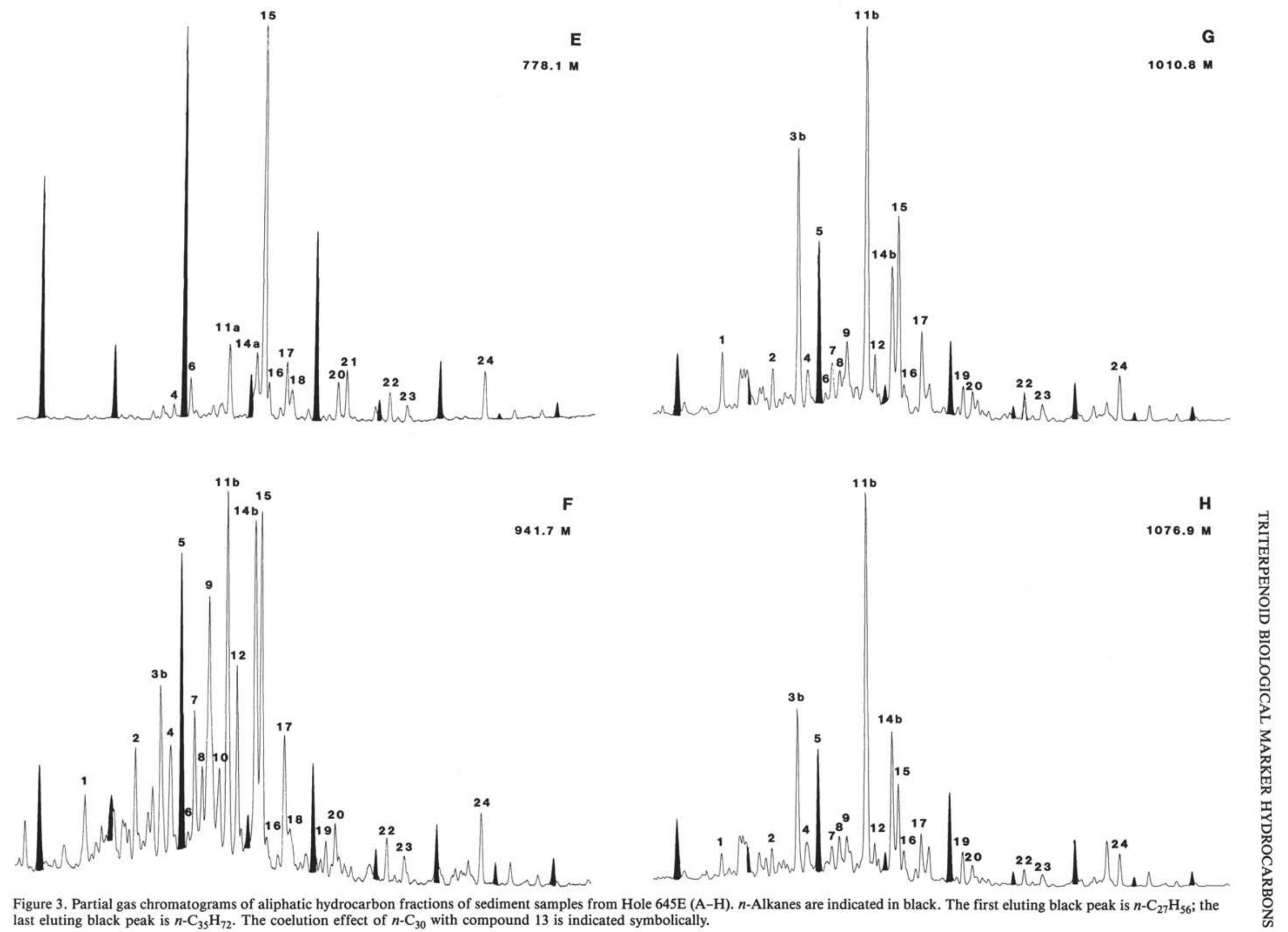

Figure 3. Partial gas chromatograms of aliphatic hydrocarbon fractions of sediment samples from Hole $645 \mathrm{E}$ (A-H). $n$-Alkanes are indicated in black. The first eluting black peak is $n$ - $\mathrm{C}_{27} \mathrm{H}_{56}$; the last eluting black peak is $n-\mathrm{C}_{35} \mathrm{H}_{72}$. The coelution effect of $n-\mathrm{C}_{30}$ with compound 13 is indicated symbolically. 
Table 2. Aliphatic hydrocarbons, identified or characterized by molecular ion $\left(\mathrm{M}^{+}\right)$and base peak(BP), that occur in sediments from Hole 645E.

\begin{tabular}{|c|c|c|}
\hline $\begin{array}{c}\text { Peak } \\
\text { no. }\end{array}$ & Compound & Mass spectral data \\
\hline 1 & Unknown (see Fig.6) & \\
\hline 2 & Unknown (see Fig.6) & \\
\hline $3 \mathrm{a}$ & Unknown (see Fig.6) & \\
\hline $3 \mathrm{~b}$ & Unknown (see Fig.6) & \\
\hline 4 & $\mathrm{C}_{28}$ triterpenoid & $\mathrm{M}^{+} 382,191(\mathrm{BP})$ \\
\hline 5 & Unknown & $\mathrm{M}^{+} 382,339(8 \mathrm{P})$ \\
\hline 6 & $17 \beta(\mathrm{H})-22,29,30$-trisnorhopane & \\
\hline 7 & Unknown (isomer of $3 \mathrm{a}$ ) & $\mathrm{M}^{+} 394(8 \mathrm{P})$ \\
\hline 8 & A/B nuclear demethylated/A-nor olean-13(18)-ene & \\
\hline 9 & A/B nuclear demethylated/A-nor olean-12-ene & \\
\hline 10 & A/B nuclear demethylated/A-nor olean-18-ene & \\
\hline $11 \mathrm{a}$ & Unknown & $\mathrm{M}^{+} 382,163(\mathrm{BP})$ \\
\hline $11 \mathrm{~b}$ & 28,30-bisnorhopane & \\
\hline 12 & A/B nuclear demethylated/A-nor urs-12-ene & \\
\hline 13 & Taraxer-14-ene & \\
\hline $14 \mathrm{a}$ & Olean-13(18)-ene & \\
\hline $14 \mathrm{~b}$ & 23-norlupane & \\
\hline 15 & Olean-12-ene & \\
\hline 16 & Olean-18-ene & \\
\hline 17 & Hop-17(21)-ene & \\
\hline 18 & Urs-12-ene +30 -normoretane & \\
\hline 19 & Neohop-13(18)-ene & \\
\hline 20 & $17 \beta(\mathrm{H}), 21 \beta(\mathrm{H})$-norhopane & \\
\hline 21 & $\mathrm{C}_{30}$ triterpenoid & $\mathrm{M}^{+} 410,191(\mathrm{BP})$ \\
\hline 22 & $17 \alpha(\mathrm{H}), 21 \beta(\mathrm{H})$-homohopane & \\
\hline 23 & $17 \beta(\mathrm{H}), 21 \beta(\mathrm{H})$-hopane & \\
\hline 24 & $17 \beta(\mathrm{H}), 21 \beta(\mathrm{H})$-homohopane & \\
\hline
\end{tabular}

olean-12-ene increases (Figs. 3A and 3B). This may be attributed to an isomerization of taraxer-14-ene to olean-12-ene. Ogihara et al. (1987) showed that taraxer-14-ene-3,24-diol isomerizes to the corresponding olean-12-ene under mild acidic conditions. Acidcatalyzed rearrangment leading directly from taraxerene to olean12-ene was demonstrated by Courtney et al. (1958). Beaton et al. (1955) argued that Clemmensen reduction of taraxerone after $8 \mathrm{hr}$ yields a mixture of olean-12-ene and olean-13(18)-ene, while a continued acid treatment yields only pure olean-13(18)ene; Brownlie et al. (1956) managed to convert olean-12-ene into olean-13(18)-ene. Although these transformation reactions are chemically feasible, alternative explanations for the change in relative concentrations cannot be completely disregarded. Taraxerene may be preferentially lost or the sedimentation rate of taraxerene (or its precursor) relative to that of the oleanenes (or their precursors) may have changed with geological time. Although we favor the transformation reaction hypothesis, an ultimate conclusion cannot be made at present with the data available.

Hydrogenation of olean-13(18)-ene would lead to $18 \alpha(\mathrm{H})$ and $18 \beta(\mathrm{H})$-oleananes (Ekweozor et al., 1979a; Riva et al., in press). $18 \alpha(\mathrm{H})$-oleanane has been identified in deltaic sediments (e.g., Ekweozor et al., 1979a; Hoffmann et al., 1984; Riva et al., 1986) and in a number of crude oils mostly related to deltaic sediments (e.g., Ekweozor et al. 1979b; Hoffmann et al., 1984; Philp and Gilbert, 1986; Riva et al., 1986; Talukdar et al., 1986; Zumberge, 1987 and references therein). A diagenetic pathway involving taraxerene to oleanene conversion can explain why no triterpanes with a taraxerane skeleton are found in sediments or oils with a pronounced terrigenous molecular signal and why oleananes are encountered.

\section{ACKNOWLEDGMENTS}

Extraction/liquid chromatography and gas chromatography were supervised by M. Radke and R.G. Schaefer (KFA Jülich, FRG), respectively. Technical assistance from U. Disko, R. Harms, B. Kammer, F. J. Keller, and H. G. Sittardt is gratefully acknowledged. We are grateful to R. Stein (now at the University of Gießen, FRG) for sampling on board the JOIDES Resolution. We thank S. C. Brassell (Stanford University) and E. S. van Vleet (University of South Florida) for their careful critique of the manuscript. This research was supported by the Deutsche Forschungsgemeinschaft (Grant No. We 346/27)

\section{REFERENCES}

Baas, W. J., 1985. Naturally occurring seco-ring-A-triterpenoids and their possible biological significance. Phytochem., 24:1875-1889.

Beaton, J. M., Spring, F. S., Stevenson, R., and Stewart, J. L., 1955. Triterpenoids. Part XXXVII. The constitution of taraxerol. J. Am. Chem. Soc., 2131-2137.

Burnouf-Radosevich, M., Delfel, N. E., and England, R., 1985. Gas chromatography-mass spectrometry of oleanane- and ursane-type triterpanes-application to Chenopodium quinoa triterpenes. Phytochem., 24:2063-2066.

Brassel, S. C., 1980. The lipids of deep-sea sediments: their origin and fate in the Japan Trench [Ph.D. dissert.]. Univ. of Bristol.

Brassell, S. C., and Eglinton, G., 1986. Molecular geochemical indicators in sediments. In Sohn, M. L. (Ed.) Organic Marine Geochemistry. Am. Chem. Soc. Symposium Series, 305:10-32.

Brassell, S. C., McEvoy, J., Hoffmann, C. F., Lamb, N. A., Peakman, T.M., and Maxwell, J. R., 1984. Isomerisation, rearrangement and aromatisation of steroids in distinguishing early stages of diagenesis. Org. Geochem., 6:11-23.

Brooks, P. W., 1986. Unusual biological marker geochemistry of oils and possible source rocks, offshore Beaufort-Mackenzie Delta, Canada. In Leythaeuser, D., and Rullkötter, J. (Eds.), Advances in Organic Geochemistry 1985: Oxford (Pergamon Journals), 401-406.

Brownlie, G., Fayez, M.B.E., Spring, F. S., Stevenson, R., and Strachan, W. S., 1956. Triterpenoids. Part XLVIII. Olean-13(18)-ene: isomerisation of olean-12-ene and related hydrocarbons with mineral acid. J. Am. Chem. Soc., 1377-1381.

Budzikiewicz, H., Wilson, J. M., and Djerassi, C., 1963. Mass spectrometry in structural and stereochemical problems. Part XXXII. Pentacyclic triterpenes. J. Am. Chem. Soc., 85:3688-3699.

Corbet, B., 1980. Origine et transformation de triterpenes dans des sediments reçents [Ph.D. dissert.]. University of Strasbourg.

Corbet, B., Albrecht, P., and Ourisson, G., 1980. Photochemical or photometic fossil triterpenoids in sediments and petroleums. J. Am. Chem. Soc., 102:1171-1173.

Courtney, J. L., Gascoigne, R. M. and Szumer, A. Z., 1958. Triterpenes of the friedelane series. Part III. The course of the friedelaneoleanane rearrangement. J. Am. Chem. Soc., 881-886.

Eglinton, G., and Hamilton, R. J., 1963. The distribution of $n$-alkanes. In Swain, T. (Ed.), Chemical Plant Taxonomy: London (Academic Press), $187-217$.

Ekweozor, C. M., Okogun, J. I., Ekong, D.E.U., and Maxwell, J. R., 1979a. Preliminary organic geochemical studies of samples from the Niger Delta (Nigeria). II. Analyses of shale for triterpenoid derivatives. Chem. Geol., 27:29-37.

$1979 \mathrm{~b}$. Preliminary organic geochemical studies of samples from the Niger Delta (Nigeria). I. Analyses of crude oils for triterpanes. Chem. Geol., 27:11-28.

Elgamal, M.H.A., Fayez, M.B.E., and Kemp, T. R., 1969. The mass spectra of some triterpenoid dehydration products. Org. Mass Spectrom., 2:175-194.

Fokina, G. A., 1979. Gas-liquid chromatography of triterpenoids. Separation of methyl esters of oleanolic and ursolic acids. Khim. Prir. Soedin., 583-584.

Hoffmann, C. F., Mackenzie, A. S., Lewis, C. A., Maxwell, J. R., Oudin, J. L., Durand, B., and Vandenbroucke, M., 1984. A biological marker study of coals, shales, and oils from the Mahakam Delta, Kalimantan, Indonesia. Chem. Geol., 42:1-23.

Karliner, J., and Djerassi, C., 1966. Terpenoids LVII. Mass spectral and nuclear magnetic resonance studies of pentacyclic triterpene hydrocarbons. J. Org. Chem., 31:1945-1956.

Leg 105 Scientific Party, 1986. End of spreading and glacial onset dated. Geotimes, 31(4):11-14.

Mackenzie, A. S., Brassell, S. C., Eglinton, G., and Maxwell, J. R., 1982. Chemical fossils: The geological fate of steroids. Science, 217: 491-504.

McEvoy, J., and Maxwell, J. R., 1983. Diagenesis of steroidal compounds in sediments from the Southern California Bight (DSDP Leg 63, Site 467). In Bjorøy, M., Albrecht, P., Cornford, C., de Groot, K., Eglinton, G., Galimov, E., Leythaeuser, D., Pelet, R., Rullköt- 
ter, J. and Speers G. (Eds.), Advances in Organic Geochemistry 1981: Chichester (John Wiley \& Sons Ltd.), 449-464.

Ogihara, K., Higa, M., Hokama, K., and Suga, T., 1987. Triterpenes from the leaves of Parsonsia laevigata. Phytochem., 26:783-785.

Philp, R. P., and Gilbert, T. D., 1986. Biomarker distributions in Australian oils predominantly derived from terrigenous source material. In Leythaeuser, D., and Rullkötter, J. (Eds.), Advances in Organic Geochemistry 1985: Oxford (Pergamon Journals), 73-84.

Riva, A., Salvatori, T., Cavaliere, R., Ricchiuto, T., and Novelli, L., 1986. Origin of oils in Po Basin, Northern Italy. In Leythaeuser D., and Rullkötter, J. (Eds.), Advances in Orqanic Geochemistry 1985: Oxford (Pergamon Journals), 391-400.

Riva, A., Caccialanza, P. G., and Quagliaroli, F., in press. Recognition of $18 \beta(\mathrm{H})$-oleanane in several crudes and Tertiary-Upper Cretaceous sediments - definition of a new maturity parameter. In Mattavelli, L., and Novelli, L. (Eds.), Advances in Organic Geochemistry 1987: Oxford (Pergamon Journals).

Rolle, F., 1985. Late Cretaceous-Tertiary sediments offshore central West Greenland, sedimentary evolution, and petroleum potential. Can. J. Earth Sci., 22:1001-1019.

Rullkötter, J., Leythaeuser, D., and Wendisch, D., 1982. Novel 23,28bisnorlupanes in Tertiary sediments. Widespread occurrence of nuclear demethylated triterpanes. Geochim. Cosmochim. Acta, 46: 2501-2509.

Rullkötter, J., Mukhopadhyay, R. K., and Welte, D. H., 1987. Geochemistry and petrography of organic matter from Deep Sea Drilling Project Site 603, lower continental rise off Cape Hatteras. In van
Hinte, J. E., Wise, S. W., et al., Init. Repts. DSDP, 93: Washington (U.S. Govt. Printing Office), 1163-1176.

Seifert, W. K., Moldowan, J. M., Smith, G. W., and Whitehead, E. V., 1978. First proof of structure of a $\mathrm{C}_{28}$-pentacyclic triterpane in petroleum. Nature, 271:436-437.

Shipboard Scientific Party, 1987. Site 645. In Srivastava, S. P., Arthur, M. A., et al., Proc. ODP, Init. Repts.,105: College Station, TX (Ocean Drilling Program), 61-418.

Schmitter, J. M., Arpino, P. J., and Guiochon, G., 1981. Isolation of degraded pentacyclic triterpenoid acids in a Nigerian crude oil and their identification as tetracyclic carboxyl acids resulting from ring A cleavage. Geochim. Cosmochim. Acta, 45:1951-1955.

Simoneit, B.R.T., 1975. Sources of organic matter in oceanic sediments [Ph.D. dissert.], University of Bristol.

Talukdar, S., Gallango, O., and Chin-A-Lien, M., 1986. Generation and migration of hydrocarbons in the Maracaibo Basin, Venezuela: an integrated basin study. In Leythaeuser, D., and Rullkötter, J. (Eds.), Advances in Organic Geochemistry 1985: Oxford (Pergamon Journals), 261-279.

Zumberge, J. E., 1987. Prediction of source rock characteristics based on terpane biomarkers in crude oils: a multivariate statistical approach. Geochim. Cosmochim. Acta, 51:1625-1637.

Date of initial receipt: 17 June 1987

Date of acceptance: 4 November 1987

Ms 105B-171 

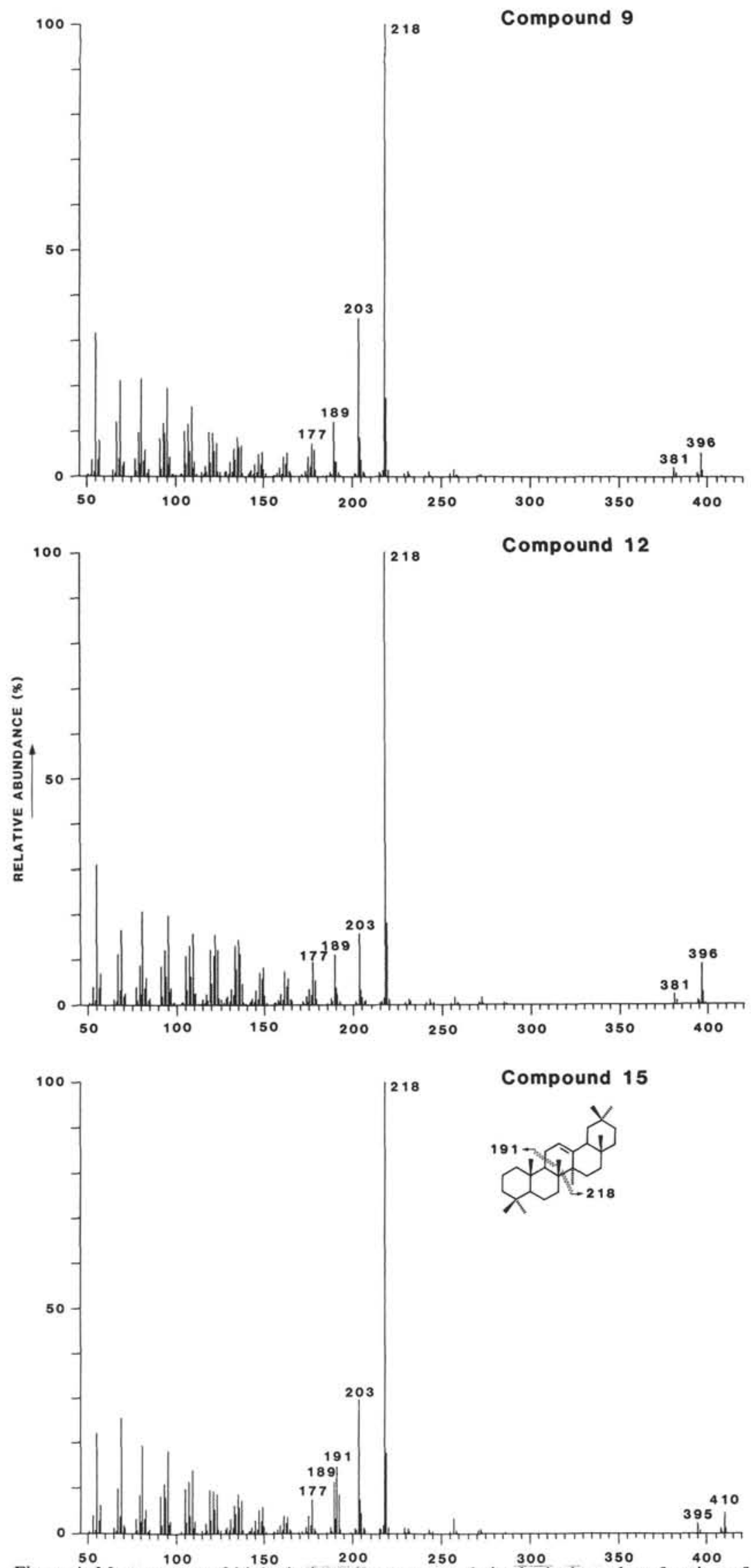

Figure 4. Mass spectra of biological-marker compounds in the hydrocarbon fraction of Site 645 samples. Compound $9=$ A/B-ring nuclear demethylated (or A-nor-) olean-12ene. Compound $12=\mathrm{A} / \mathrm{B}$-ring nuclear demethylated (or A-nor-) urs-12-ene. Compound $15=$ olean-12-ene. 


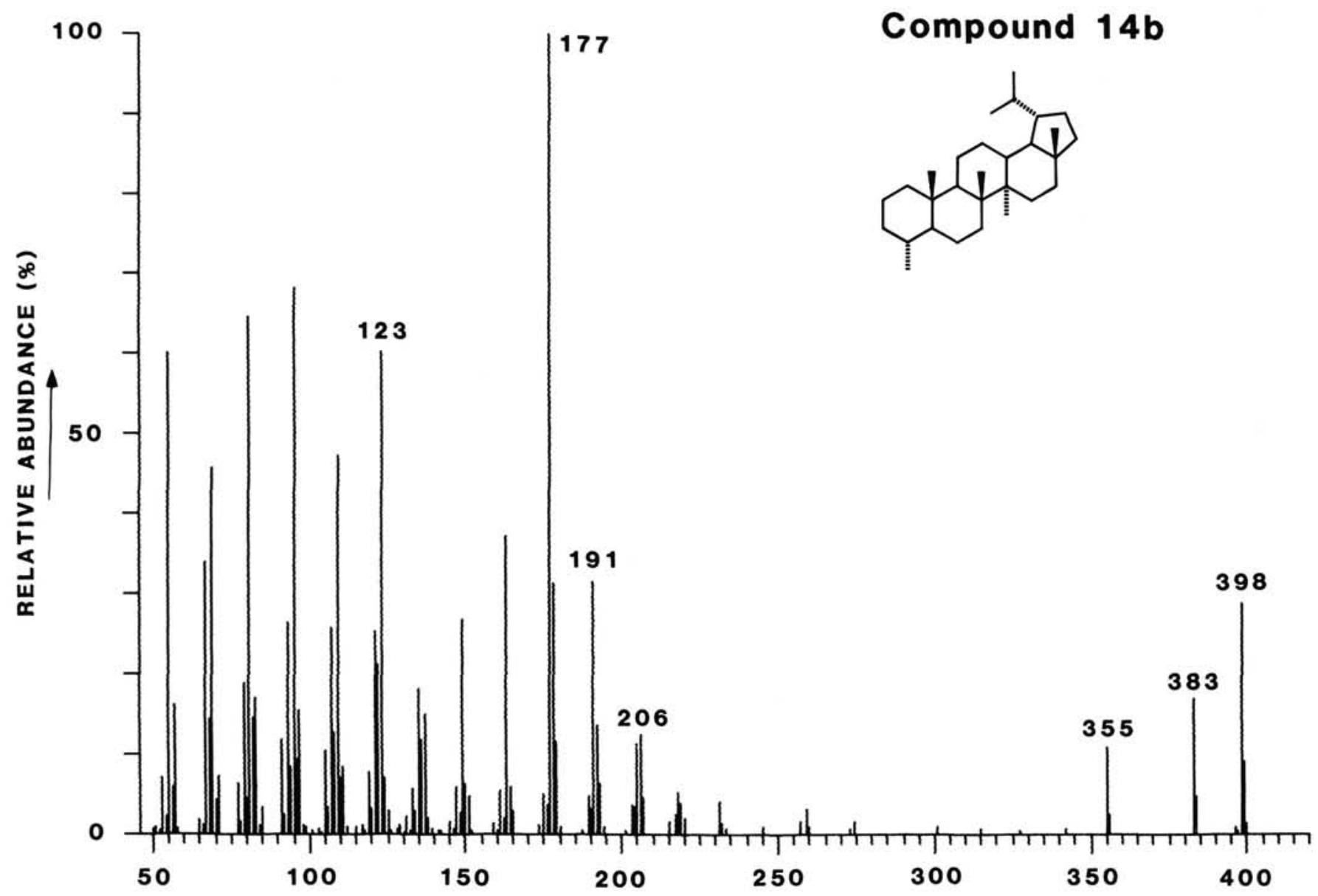

Figure 5. Mass spectrum of compound $14 \mathrm{~b}$, tentatively identified as a 23 -norlupane. 

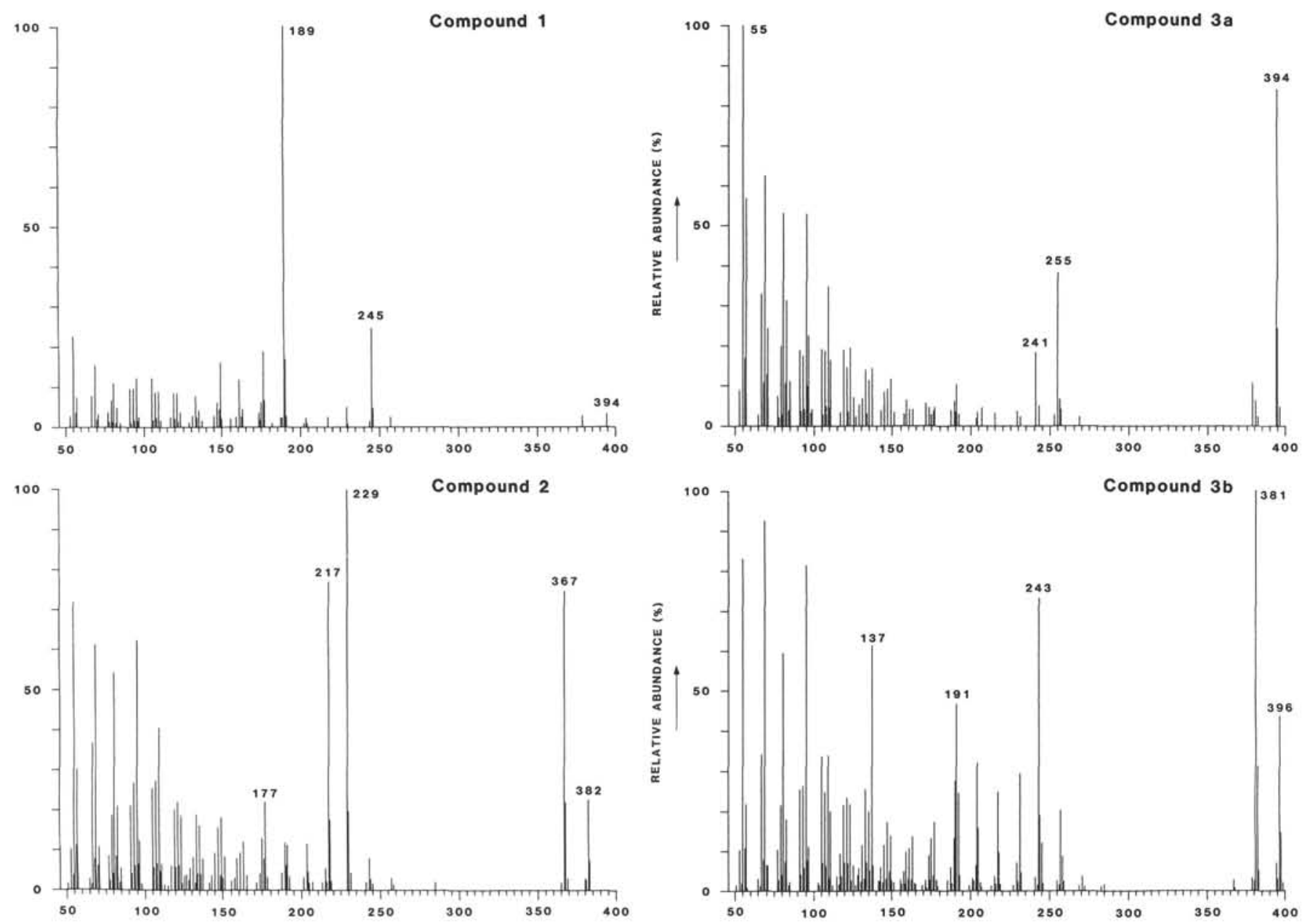

Figure 6. Mass spectra of some selected unknown compounds in the aliphatic hydrocarbon fraction of Site 645 samples.

\section{APPENDIX}

Chemical Compound Structures
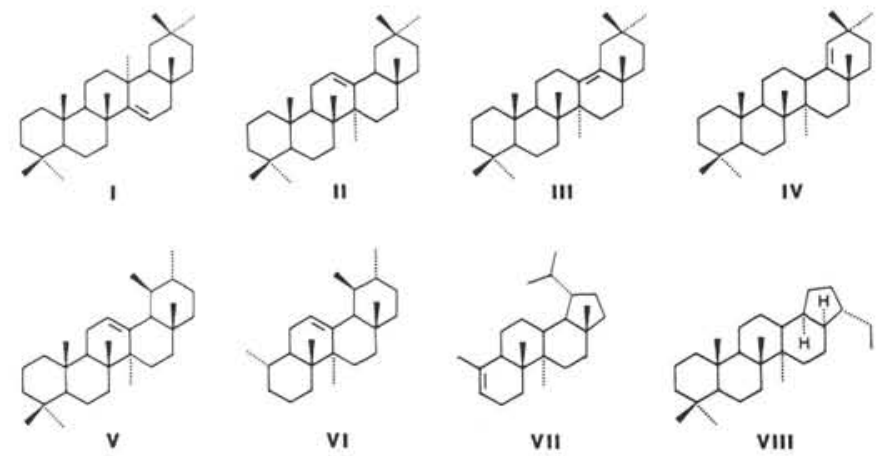<smiles>CC1CCC2CCC1CC21CCCC(C)C1C</smiles><smiles>CC1=CCCC2C1CCC1CC=CC12</smiles>

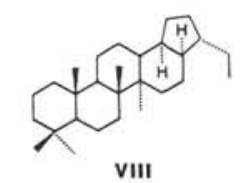

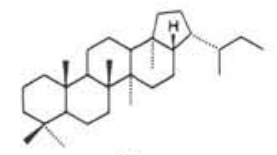

IX
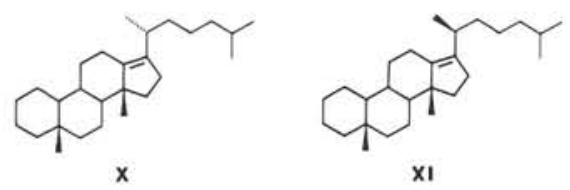